\title{
The Association between the Operating Efficiency of Taiwanese FDI Enterprises in Mainland China and the Investment Performance of Their Parent Companies
}

\author{
Wang Jui-Chih, Hsiao Hsing-Chin \\ Department of Accounting Information, National Taipei University of Business, Taipei City, Taiwan \\ Email: jcwang@ntub.edu.tw, thinking@ntub.edu.tw
}

Received 30 May 2014; revised 30 June 2014; accepted 9 July 2014

Copyright (C) 2014 by authors and Scientific Research Publishing Inc. This work is licensed under the Creative Commons Attribution International License (CC BY). http://creativecommons.org/licenses/by/4.0/

(c) (i) Open Access

\begin{abstract}
This paper uses data envelopment analysis and seemingly unrelated regression estimation model to examine the association between the operating efficiency of Taiwanese FDI enterprises in mainland China and the investment performance of their parent companies. We find that the more capital-intensive Taiwanese FDI enterprises in mainland China have higher operating efficiencies. Enterprises investing in East China area have lower operating efficiency. In addition, higher operating efficiencies of FDI enterprises in mainland China are associated with higher investment performance of the Taiwanese parent companies. The Taiwanese parent companies with greater investment of FDI enterprises in mainland China also have higher investment performance. The Taiwanese parent companies with higher $R$ \& $D$ expenditure percentages do not result in improved investment performance because of a lack of spillover to FDI subsidiaries or more uncertain factors. Furthermore, the wholly-owned investment type of a parent company has greater investment performance than joint-venture investment type.
\end{abstract}

\section{Keywords}

Taiwanese FDI Enterprises in Mainland China, DEA, Operating Efficiency, Investment Performance

\section{Introduction}

After China began the economic reform and opening-up policy, the Chinese government was eager to introduce foreign capital and technology for promoting the industrialization and urbanization. From the overall economic 
perspective, China’s GDP in 2013 amounted to $\$ 9185$ billion USD, the average economic growth in the seven-year period (2007 to 2013) is $9.74 \%$, indicating that the Chinese economy as a whole has a rapid and stable growth trend. China has approved nearly 730,000 foreign direct investment (FDI) enterprises with investment amount of \$1.2 trillion USD and has become the first largest developing country attracting FDI in the world. According to the 2011 statistics, the top ten countries or regions investing in China are: Hong Kong (77.01 billion USD), Taiwan (6.73 billion USD), Japan (6.35 billion USD), Singapore (6.33 billion USD), the US (2.99 billion USD), Korea (2.55 billion USD), the UK (1.61 billion USD), Germany (1.14 billion USD), France (0.80 billion USD), and the Netherlands (0.77 billion USD). The investment amount of the ten countries or regions accounted for $91.61 \%$ of the total. Taiwanese enterprises rank the second and are predominant in the Chinese market.

Taiwanese enterprises are the pioneers of FDI and have occupied important economic position in mainland China. In 1980s, Taiwanese enterprises established the labor-intensive industries in the four economic development zones (Shenzhen, Zhuhai, Xiamen, and Shantou). In the early 1990s, the Chinese opening-up policy continued northward to Shanghai, and later, more cities along the river (Yangtze River), the coast, and the border. As a result, Taiwanese investment moved northward and shifted from labor-intensive to technology and capitalintensive industries. Taiwanese government approved 237 cases of investment in mainland China with the amount of 174 million USD in 1991 and increased rapidly to 40,762 investment cases with the amount of 133.7 billion USD in 2013, more than $62 \%$ of the total outward direct investment. At the end of 2013, the top three industries of Taiwanese FDI in mainland China were electronic component manufacturing (18.89\%), computers, electronics and optical products manufacturing (13.61\%), and electrical equipment manufacturing (7.24\%), which accounted for $39.74 \%$ of the total approved amount. Meanwhile, the investment of Taiwanese enterprises in coastal cities of East China accounted for $71.58 \%$ of the total due to geographic environment, traffic and climate. The investment in North China accounted for only 5.01\% while the investment in Central China accounted for $22.92 \%$ of the total.

Previous literature mostly focuses on the location distribution of FDI enterprises in mainland China (Klimberg \& Ratick, 2008; Foster, 2011; Chen \& Yeh, 2012; Liu et al., 2012; Yu \& Shen, 2013; Sharma et al., 2014), the performance evaluation of FDI, or the determinants of FDI performance in mainland China (Li et al., 2000; Beamish \& Jiang, 2002; Wei et al., 2002; Mohr \& Puck, 2005; Lu \& Hung, 2010; Zhong et al., 2011; Guo \& Jiang, 2013). Some studies focus mostly on measuring or analyzing the subsidiary's performance in mainland China (Li et al., 2000; Beamish \& Jiang, 2002; Mohr \& Puck, 2005; Lu \& Hung, 2010; Guo \& Jiang, 2013). There are scanty studies on simultaneous analysis of operating efficiency of FDI in mainland China and investment performance of parent companies. With rapidly growing economic market of China in the world and the predominant Taiwanese enterprises in mainland China, it is essential to understand the association between operating efficiency of Taiwanese FDI enterprises in mainland China and investment performance of their parent companies.

Our research is to examine the operating efficiency of Taiwanese FDI enterprises in mainland China by using data envelopment analysis (DEA), and apply the SURE (seeming unrelated regression estimation) to simultaneously explore the operating efficiency of Taiwanese FDI subsidiaries in mainland China and the investment performance of parent companies in Taiwan. We find that the more capital-intensive Taiwanese FDI enterprises in mainland China have higher operating efficiencies. Enterprises investing in the East China area, where competition and the costs of land and labor are higher, have lower operating efficiency. In addition, we find that higher operating efficiencies of Taiwanese FDI enterprises in mainland China are associated with higher investment performance of the Taiwanese parent companies. The Taiwanese parent companies with greater investment of FDI enterprises in mainland China also have higher investment performance. The Taiwanese parent companies with higher R \& D expenditure percentages do not have improved investment performance because of a lack of spillover to FDI subsidiaries or more uncertain factors. Furthermore, the wholly-owned investment type of a parent company has the greater investment performance than joint-venture investment type due to the greater control of business operations and efficiency of decision making.

The contributions of this study are as follows. First, it simultaneously analyzes the operating efficiency of Taiwanese FDI enterprises in mainland China and the investment performance of their parent companies. As the China market has become increasingly competitive and Taiwanese firms have more powerful position in mainland China, simultaneously analyzing the influencing factors of the operating efficiency of FDI in mainland China and the investment performance of parent companies in Taiwan would provide insights for enterprises' 
managers seeking for improvement in operating performance and for policymakers considering outward investment regulations.

Second, this study enriches the literatures related to evaluate the operating efficiency of FDI in mainland China and investment performance of Taiwanese parent company. Most past studies only focused on the subsidiary’s performance in mainland China or on home company. This study is the first to provide evidence of simultaneous analysis of operating efficiency of FDI in mainland China and investment performance of parent company.

Third, our study provides additional empirical evidence on performance of FDI enterprises and their parent companies in developing countries. China has become the first largest developing country attracting FDI in the world. Due to developing countries where markets and institutional structures are different from those of developed countries, understanding the operating efficiency of FDI enterprises in mainland China and the investment performance of their parent companies are particularly important.

The remainder of this paper is organized as follows. Section 2 reviews the literature review of operating efficiency and investment performance, and further develops the empirical hypotheses. Section 3 describes the DEA and regression models, and data and sample selection. Section 4 discusses the empirical results and the sensitivity analyses. Section 5 offers conclusions, and proposes managerial implications, research limitations and future research directions.

\section{Literature Review and Hypotheses Development}

\subsection{The Operating Efficiency of FDI in Mainland China}

According to the Transaction Costs Theory, multinational enterprises (MNEs) invest abroad to reduce transaction costs (Hennart, 1991). In Adam Smith's The Wealth of Nation, he argued that the countries with the most efficient products should trade with other countries, in order to increase operational efficiency and enhance the wealth among the nations.

Lu \& Hung (2010) applied Data Envelopment Analysis (DEA) approach to measure the performance efficiency of 31 companies of Taiwan in mainland China. The results were conducive to the planning of resource allocation, competitive advantages, strategic decision-making, and operational styles under an intensely competitive environment. Beamish \& Jiang (2002) argued that companies, which entered the Chinese market earlier, have more established years, as well as more human and natural resources. Moreover, investment years in mainland China and the performance of the subsidiary are significantly positive. However, Wei et al. (2002) studied the correlation between China's manufacturing industry and its performance, and defined the companies entering the Chinese market before 1978 as "old companies", while those after 1978 as "new companies". They found that old companies have lower productivity and poorer performance; on the contrary, the "new companies”, which have new facilities, better management system and employee benefits, have better performance.

Our study argues that enterprises entering the Chinese market in earlier times are more familiar and more adapted to local politics, society, culture and regulations, and have built political, social, and economic ties. Hence, they have more human resources and market control, including market share and sales channel, customer loyalty or company brand, as well as more power to prevent newcomers from entering the market. Therefore, more established years in the Chinese market means more investment experience, more market control power and human resources, and thus the operating efficiency will be higher. Thus, we construct our hypothesis as follows:

H1-1: Ceteris Paribus, The operating efficiency of Taiwanese FDI enterprises in mainland China with more established years is higher.

Previous literature had found that the large MNEs from western countries chose the capital intensive and technology intensive investment strategies for easy access to China's vast market share, and provided high quality and complex diversified products for the customers in mainland China and around the world. To achieve this competitive advantage, companies have gradually transferred numerous technologies to China. From 1952 to late 2013, Taiwanese FDI in electronic component, computers, electronics and optical products, and electrical equipment manufacturing accounted for $39.74 \%$ of the total. It is obvious that the Taiwanese FDI in mainland China took the strategies similar to those of western countries, focusing on capital and technology-intensive investment and injecting more capital.

Li et al. (2000) explored the strategic consideration factors of FDI in mainland China, and reviewed the impact of capital and technology intensity or labor intensity investment strategies on the performance of subsidiar- 
ies. They found that the capital and technology intensive investment strategies result in better performance as compared to labor intensive investment strategy. Liu \& Daly (2011) confirmed that manufacturing companies of FDI in mainland China transformed from low-tech to high-tech. Guo \& Jiang (2013) examined the contributions of venture capital investment to entrepreneurial companies in mainland China. The results showed that venture-capital-backed companies outperform non-venture-capital-backed companies in terms of profitability, labor productivity, sales growth, and R \& D investment. In summary, companies with higher capital intensity expect to effectively increase output, reduce product unit cost, improve product quality and produce diversified products, and more effectively prevent potential competitors from entering the market. We therefore anticipate that higher capital intensity of Taiwanese FDI enterprises can result in higher operating efficiency. Thus, the hypothesis is stated as follows:

H1-2: Ceteris Paribus, The operating efficiency of Taiwanese FDI enterprises in mainland China with higher capital-intensity is higher.

Past studies of transnational business management have found that the most important decision factor is the location selection. Foster (2011) found that FDI in mainland China is heavily skewed in favor of the richest east region, while the west region is the weakest attractor. Liu et al. (2012) analyzed the relative importance of the potential determinants of FDI inflows across the four regions of China for the period 2001-2009. The determinants examined were: market size, labor cost, labor quality, physical infrastructure development, telecommunication, and degree of economic openness and government incentives to attract FDI. They found that that market size holds priority for FDI inflows into coastal and northeast regions. Chen \& Yeh (2012) examined variations in the preferences of location antecedents and the pace of FDI by MNEs in relation to increased FDI experience and evolved strategic intentions.

Different invested locations result in varied investment costs, transaction costs, transport time, tax costs, infrastructure, political risk, and staff quality. Hence, Taiwanese FDI enterprises prefer certain economic regions. East region, which has the longest coastline in mainland China, is nearest to Taiwan with extensive internal and external links, convenient transportation, and advanced communications to attract foreign companies. At present, Shanghai Pudong New District has been expanded into an open economic zone, and become the largest base of Chinese industrial technology and also an important international port city in the Western Pacific region. Therefore, most of Taiwanese FDI is in East China, accounting for $71.58 \%$ of the investment amount. With more and more foreign companies entering East China, the labor and land tax costs increase accordingly. Increasing labor costs has a negative impact on the business performance. Therefore, we expect that labor costs in East China will be higher due to the increasing number of foreign companies, thereby reducing the operating efficiency of FDI. The hypothesis is proposed as follows:

H1-3: Ceteris Paribus, Taiwanese FDI enterprises located in East China have lower operating efficiency.

\subsection{Performance of Parent Companies}

There are scanty studies concerning the impact of operating performance in the manufacturing sector on investment performance. Lin (2010) investigated the factors that affect Taiwanese companies' intention to engage in FDI in mainland China. He found that network linkages, expansion of market, and China's incentive policies positively affect the intention to engage in FDI. A company with a higher degree of export orientation and larger company size has a stronger motivation in FDI. Fung et al. (2013) investigated whether FDI in mainland China displaces or promotes parent companies' exports. They found that FDI in mainland China reduces parent companies' exports, suggesting a substitutive relationship. Therefore, we anticipate that higher operating efficiency of FDI enterprises in mainland China will result in more investment returns of Taiwanese parent companies. Thus, the hypothesis is proposed as follows:

H2-1: Ceteris Paribus, Taiwanese parent companies with higher operating efficiency of FDI enterprises in mainland China have better investment performance.

Some researches (Sougiannis, 1994; Lev \& Sougiannis, 1996; Green et al., 1996) argue that R \& D activities can improve the operating technology and business performance. Due to the externality of $\mathrm{R} \& \mathrm{D}$ activities (Jaffe, 1986; D’Aspremont \& Jacquemin, 1988; Kogut \& Zander, 1993), other companies can also improve the production technology through intermediate and investment capital trading or technological knowledge dispersion. Previous studies have found that R \& D activities externality can be commonly found in various industries and between subsidiaries of the group company (Bernstein, 1988; Goto \& Suzuki, 1989; Klette, 1996), in partic- 
ular, the high-tech industry (Bernstein \& Nadiri, 1988).

Zhong et al. (2011) used DEA models to evaluate the relative efficiencies of 30 regional R \& D investments using the First Official China Economic Census data in 2004. The empirical analysis provided the suggestions to improve efficiencies of regional R \& D investments. Our study adopts the resource-based theory (Barney, 1986; Itami, 1987) and externality effects of R \& D activities, therefore anticipates that the more of R \& D activities of the parent companies will result in better investment performance. The hypothesis is proposed as follows:

H2-2: Ceteris Paribus, Taiwanese parent companies with more $\mathbf{R} \& \mathbf{D}$ expenses have better investment performance.

Internationalization is the overseas expansion process of an enterprise in its various business activities (Hitt et al., 1997). Many studies have proposed internationalization perspectives related to FDI, including the Theory of Absolute Advantage, the Transaction Costs Theory, the Product Life Cycle Theory, the Network Theory, the Theory of Location Advantages, and the Entry Strategy Theory. Daniels and Bracker (1989) argued that the benefits of internationalization include reduced risks, tax saving, lower financing costs, and access to raw materials and labor of lower costs. MNEs prefer FDI to internalize equipment, capital, knowledge and skills to save transaction costs for improving competitive advantage.

Many studies have explored the correlation between the investment involvement degree in mainland China and the financial performance or operating performance of the parent companies. Our study argues that Taiwanese FDI in mainland China is based on internationalization theory. The higher investment amounts indicate a higher degree of investment involvement, which can bring valuable business management experiences and reduce transaction costs, uncertainty and failure risks, thereby improving the performance of the parent companies. Therefore, the hypothesis is proposed as follows:

H2-3: Ceteris Paribus, Taiwanese parent companies with higher investment amounts in mainland China have better investment performance.

Previous studies have found that ownership structure or entry mode affects the Japanese subsidiaries in the US and West Europe. However, the impact on the entry mode of FDI in mainland China is inconclusive. Some studies suggest that entry mode and the performance of subsidiary are not significantly correlated (Li et al., 2000), while others regard China as a destination of high political risk and uncertainty. MNEs may reduce or disperse risks and costs by joint venture or cooperation with local partners. Hence, the business performance will be better (Pan et al., 1999; Beamish \& Jiang, 2002; Wei et al., 2002).

After many years of economic reform and opening up issued by China, the degree of economic freedom and free market competition is higher, and foreign investors are more familiarized with China's politics, political community, and regulations. As a result, the percentage of wholly owned FDI enterprises will be higher. Under this situation, Taiwanese investors are more unwilling to cooperate with local partners because there are risks of conflicting goals, business secret leakage and being taken over by the local partners. The parent companies with wholly owned investment type have better control over the business operations and decisions. Therefore, we anticipate that the impact of wholly owned FDI enterprises have a greater positive impact on the investment performance of the parent company. The hypothesis is proposed as follows:

H2-4: Ceteris Paribus, Taiwanese parent companies with wholly-owned FDI enterprises in mainland China have better investment performance than joint-venture.

\section{Methodology}

\subsection{DEA Models}

Data envelopment analysis (DEA) is an effective tool for evaluating the relative efficiency of peer decision making units (DMUs) when multiple performance measures are present. It has been used to evaluate operating efficiency of firms in mainland China (Byrnes and Storbeck, 2000; Shiu, 2002; Ma \& Goo, 2005).

Efficiency can be measured as the minimal consumption of inputs for a given level of output or the maximal augmentation of outputs for a given level of inputs. Since it is potentially difficult for banks to increase their output levels given their input levels, we adopt an input-based approach measure, focusing on minimizing inputs consumed for a given level of output. The input-oriented efficiency measure is the efficiency measure, which can be estimated using the following CCR model (Charnes et al., 1978) of DEA:

$$
\text { Min } \theta
$$




$$
\begin{array}{r}
\text { s.t. } \sum_{j=1}^{n} \lambda_{j} x_{i j} \leq \theta x_{i k}, \quad i=1,2, \cdots, m \\
\sum_{j=1}^{n} \lambda_{j} y_{r j} \geq y_{r k}, \quad r=1,2, \cdots, s \\
\lambda_{j} \geq 0, \quad j=1,2, \cdots, n
\end{array}
$$

where $j$ is the firm being evaluated, $\theta_{j}$ is the estimated efficiency for firm $j, X_{i j}$ is input $i$ for firm $j$, $Y_{r j}$ is output $r$ for firm $j$, and $\lambda$ is the weight placed on banks. Model (1) is constructed under the assumption of constant return to scale (CRS) technology and referred to as the CCR model of DEA. If the CRS assumption is re laxed and allows variables returns to scale (VRS) technology, the constraint $\sum_{j=1}^{n} \lambda_{j}=1$ is added to the model and the resulting model is referred to as the BCC model of DEA (Banker et al., 1984). The CCR model is to measure the total technical efficiency (TE) of DMUs in the utilization of input resources and operating scale performance. The BCC model only measures the pure technical efficiency (PTE) of input resources when DMUs are at the optimal operating scale.

The $\theta$ value is between 0 and 1. If the input of individual DMU can be reduced proportionally, as compared to the one with the optimal efficiency, the value of $\theta$ will be below 1; otherwise, if the input cannot be reduced proportionally, the value of $\theta$ will be equal to 1 , and thus it is at the state of optimal efficiency.

Tsai et al. (2006) used total assets, capital, and number of employees as the inputs; revenue and pre-tax and pre-interest net profit as the outputs. However, Düzakin \& Düzakin (2007) argued that assets and shareholder equities cannot be used as inputs at the same time, while revenue and profit cannot be used as the outputs at the same time. Oberholzer (2013) considered the operating efficiency as sales opposed to the input resources. Therefore, according to Düzakin \& Düzakin (2007) and Oberholzer (2013), this paper uses the total assets $\left(I N P \_T A\right)$ and number of employees $\left(I N P \_N\right)$ of Taiwanese FDI enterprises as the input variables, and total revenue $\left(O U T_{-} S\right)$ as the output variables to measure operating efficiency of a firm. Moreover, this paper evaluates total technical efficiency (TE) and pure technical efficiency (PTE) based on the input-oriented CCR model and BCC model.

\subsection{Regression Model}

We use the second-stage procedure in Equations (2) and (3) to explore the effect of firm contextual variables on the operating efficiency of Taiwanese FDI enterprises in mainland China and the investment performance of their parent companies based on prior research (Banker \& Natarajan, 2008). We evaluated the values of total technical efficiency (TE) and pure technical efficiency (PTE) from model (1) which are the dependent variable in model (2) and constructed the simultaneous models (2) and (3) are as follows:

$$
\begin{aligned}
& T E_{i t} / P T E_{i t}=\alpha_{0}+\alpha_{1} \text { YEARS }_{i t}+\alpha_{2} \text { CINT }_{i t}+\alpha_{3} \text { DAREA }_{i t}+\alpha_{4} \text { DIND }_{i t}+\alpha_{5} \text { CSIZE }_{i t} \\
& +\alpha_{6} C D A_{i t}+\alpha_{7} C R O A_{i t}+\alpha_{8} P P T O_{i t}+\alpha_{9} C G D P_{i t}+e_{i t} \\
& R O I_{i t}=\beta_{0}+\beta_{1} T_{i t} / P T E_{i t}+\beta_{2} R D_{i t}+\beta_{3} A M O U N T_{i t}+\beta_{4} D T Y P E_{i t}+\beta_{5} E L E C_{i t}+\beta_{6} R E_{i t} \\
& +\beta_{7} P P E_{i t}+\beta_{8} G R O W T H_{i t}+\beta_{9} \text { TROA }_{i t}+\beta_{10} T D A_{i t}+\beta_{11} T_{S I Z E_{i t}}+\beta_{12} T G D P_{i t}+\varepsilon_{i t}
\end{aligned}
$$

\subsection{Variables Measurement}

\subsubsection{Dependent Variables}

Operating efficiency (TE, PTE): This paper evaluates total technical efficiency (TE) by CCR model and pure technical efficiency (PTE) by BCC model.

Investment performance (ROI): It is measured by the ratio of the recognized investment benefits from FDI enterprises and the pre-tax net profit of the parent companies. It is expected that higher operating efficiency can result in better investment performance of the parent companies.

\subsubsection{Independent Variables (Hypothesis Variables)}

Experience of entry into the Chinese market (YEARS): According to Beamish \& Jiang (2002), the experience 
of entry into the Chinese market is measured by the established years of FDI enterprises. If the firm enters the Chinese market at an earlier time, it is more familiar with and adapted to the Chinese market with more human resources and market control power, and thus, the operating performance will be higher. It is measured by the Taiwanese FDI enterprises' entrance years in mainland China and is expected that longer establishment years can result in higher operating efficiency.

Capital intensity (CINT): Following Hu \& Chen (1996), Li et al. (2000), Chen \& Ku (2000), this study uses the ratio of the total fixed assets by the number of employees to measure the capital intensity. It is expected that higher capital intensity can result in higher operating efficiency.

Invested area (DAREA): The invested area of Taiwanese companies can be roughly divided into East China, North China, Central China, South China, Northeast China, Northwest China and Southwest China. As the number of Taiwanese investment in East China is more than 70.58\%, this study measures the invested area by the dummy variable, DAREA = 1, if the FDI enterprise is located in East China, otherwise, DAREA = 0. We expect that the FDI enterprise in East China has lower operating efficiency.

$\underline{\mathrm{R}}$ \& D ratio $(R D)$ : It is measured by the division of the $\mathrm{R} \& \mathrm{D}$ expense of the parent companies by the total assets. It is expected that higher $\mathrm{R} \& \mathrm{D}$ expenditure can result in higher investment performance.

Investment amount (AMOUNT): It is measured by using the natural logarithm of the capital investment of the FDI enterprise. It is expected that higher investment amount can result in better investment performance.

Wholly-owned investment type (DTYPE): The ownership structure of FDI enterprises in mainland China can be divided into the wholly-owned investment type (Hong Kong, Macao and Taiwan enterprises, foreign-invested enterprises) and joint venture investment type (Hong Kong, Macao and Taiwan joint ventures, cooperative enterprises, Macao and Taiwan, Sino-foreign joint business enterprises and Sino-foreign cooperative joint venture); if the enterprise belongs to the wholly-owned investment type, then DTYPE $=1$, if the firm belongs to the joint venture type, $D T Y P E=0$. It is expected that the investment performance of the parent company will be better if the FDI enterprise belongs to the wholly-owned investment type.

\subsubsection{Control Variables}

Control variables in equations include Taiwanese FDI subsidiaries characteristics and parent companies characteristics, which are defined and measured as following: DIND: Subsidiary industry, measured as dummy variable $=1$, if the subsidiary belong to information electronic and communication equipment; and 0 otherwise. CSIZE: Subsidiary size, measured as the logarithm of total assets. CDA: Subsidiary debt-to-asset ratio, measured as total liabilities divided by total assets. CROA: Subsidiary return on assets, measured as income from operation divided by total assets. PPTO: Subsidiary turnover on PPE, measured as sales divided by total assets. CGDP: China GDP, measured as the ratio of GDP growth in mainland China. ELEC: Parent company industry, measured as dummy variable $=1$, if the parent company belong to electronic industry; and 0 otherwise. $R E$ : Parent company retained earnings ratio, measured as net income less the salary of director and supervisor, cash and stock dividends to employee and shareholders divided by net income. PPE: Parent company PPE ratio, measured as cash outflows to purchase PPE divided by total assets. GROWTH: Parent company growth ratio, measured as market value of equity divided by book value. TROA: Parent company return on assets, measured as income before tax and interest divided by total assets. TDA: Parent company debt-to-asset ratio, measured as total liabilities divided by total assets. TSIZE: Parent company size, measured as the logarithm of total assets. TGDP: Taiwan GDP, measured as the ratio of GDP growth in Taiwan.

\subsection{Data and Sample}

It is very difficult to acquire the financial statements of Taiwanese FDI enterprises in mainland China, the data are surveyed in mainland China from CCIS. The financial data, investment gains and losses, and the cumulative outbound investment amount of the parent companies are from the financial statement of listed companies in Taiwan's stock market and TEJ database. Due to simultaneously analyzing the operating efficiency of FDI enterprises in mainland China and the investment performance of Taiwanese parent companies, we exclude the unlisted parent companies and their subsidiaries in mainland China because the data is not available. This study first locates 780 firm-year samples from the investigation of the top 1000 Taiwanese FDI enterprises in mainland China from CCIS, then to combine the data of their parent companies from TEJ, after deleting 132 missing or incomplete observations. The final sample consists of 648 firm-year observations. 
Since the enactment of the new Corporate Income Tax Law and the Labor Contract Law in mainland China on January 1,2008 , the corporate income tax law has been unified income rate at $25 \%$. It gradually increases from the tax preferential $15 \%$ to $25 \%$; meanwhile, the tax preferential treatment on FDI, including the tax exemption and rebates, as well as the preferential tax rates for specific zones, has been terminated to result in a direct impact on the profits of the firm. The enactment of the Labor Contract Law affects the enterprises mostly in working hours and overtime pay, which substantially increases the labor cost burden of the enterprises. Due to the new income tax laws enacted after 2008, our research period is limited from 2004 to 2007 to avoid the tax system interference.

\section{Results and Discussion}

\subsection{Descriptive Statistics}

Panel A of Table 1 provides the descriptive statistics of the input and output variables of DEA model. Operating revenue (OUT_S) is an output variable and its mean during 2004-2007 is 2384 million RMB; total assets (INP_TA) and number of employees (INP_N) are input variables; the mean (median) of total assets is 1110 (469) million RMB; the mean (median) number of employees is 2668 (985); representing that investment amount and operating results vary significantly for Taiwanese enterprises in mainland China. Panel B presents the descriptive statistics of operating efficiency and investment performance, the mean of total technical efficiency $(T E)$ is 0.1899 , and pure technical efficiency (PTE) is 0.2583. The mean of parent companies' return on investment ( $R O I$ ) is $13.11 \%$, the higher $R O I$ is $160.67 \%$, and the worst $R O I$ is $-188.4 \%$. Therefore, Taiwan FDI enterprises in mainland China have different performances.

Table 1. Descriptive Statistics on inputs, outputs, and the control variables in regression analysis.

\begin{tabular}{|c|c|c|c|c|c|c|c|}
\hline \multicolumn{8}{|c|}{ Panel A: DEA-Inputs and Outputs Variables } \\
\hline Variables & Min. & Q1 & Mean & Median & Std. Dev. & Q3 & Max. \\
\hline $\begin{array}{c}\text { OUT_S } \\
(\mathrm{RMB} \$ 1000)\end{array}$ & 51731 & 273,806 & $2,384,815$ & 505,696 & $12,094,104$ & $1,150,496$ & $193,122,284$ \\
\hline $\begin{array}{c}\text { INP_TA } \\
(\mathrm{RMB} \$ 1000)\end{array}$ & 27,649 & 261,217 & $1,109,681$ & 469,368 & 3181743 & 991121 & $54,948,703$ \\
\hline $\begin{array}{c}I N P \_N \\
\text { (Numbers) }\end{array}$ & 50 & 462 & 2668.02 & 985 & 11159.43 & 2050 & 187,689 \\
\hline \multicolumn{8}{|c|}{ Panel B: Simultaneous Equation-Dependent Variables } \\
\hline Variables & Min. & Q1 & Mean & Median & Std. Dev. & Q3 & Max. \\
\hline$T E$ & 0.01 & 0.10 & 0.19 & 0.15 & 0.15 & 0.22 & 1 \\
\hline PTE & 0.04 & 0.14 & 0.26 & 0.20 & 0.19 & 0.31 & 1 \\
\hline ROI (\%) & -188.41 & 1.09 & 13.11 & 7.14 & 39.07 & 23.56 & 160.67 \\
\hline \multicolumn{8}{|c|}{ Panel C: Simultaneous Equation-Hypotheses Variables } \\
\hline Variables & Min. & Q1 & Mean & Median & Std. Dev. & Q3 & Max. \\
\hline YEARS & 0 & 4 & 7.44 & 7 & 3.74 & 10 & 19 \\
\hline $\begin{array}{c}\text { CINT } \\
\text { (RMB NT\$1000) }\end{array}$ & 1.11 & 76.53 & 296.65 & 171.13 & 336.44 & 359.46 & 1304.49 \\
\hline DAREA $(0,1)$ & 0 & 0 & 0.67 & 1 & 0.47 & 1 & 1 \\
\hline$R D(\%)$ & 0 & 0.30 & 1.42 & 1.02 & 1.42 & 2.17 & 7.10 \\
\hline $\begin{array}{c}\text { AMOUNT } \\
\text { (RMB \$1000) }\end{array}$ & 5,795 & 89,771 & 231,054 & 158,629 & 309,503 & 297,128 & $5,430,588$ \\
\hline AMOUNT (log) & 8.66 & 11.40 & 11.90 & 11.97 & 0.98 & 12.60 & 15.51 \\
\hline DTYPE $(0,1)$ & 0 & 1 & 0.86 & 1 & 0.35 & 1 & 1 \\
\hline
\end{tabular}


Panel C presents the descriptive statistics of hypotheses variables. The mean of the established years (YEARS) of FDI enterprises in mainland China is 7.44 years. The firm with the longest history among the samples is 19 years old. The mean capital intensity (CINT) is 297 thousand RMB per capita. By invested area (DAREA), about 67\% firms are located in East China. Regarding the parent company characteristic variables, the mean Taiwanese FDI enterprises' $\mathrm{R} \& \mathrm{D}$ ratio $(R D)$ is $1.42 \%$, the mean investment amount (AMOUNT) is 231 million RMB, and the median is 159 million RMB. Most of the FDI enterprises are wholly owned investment mode (DTYPE) from Hong Kong, Macao and Taiwan, accounting for $86 \%$ of the total samples. Meanwhile, the parent companies of FDI enterprises mostly belong to the electronics industries (ELEC), and the percentage are reaching up $48 \%$.

\subsection{Univariate Analyses}

To explore the impact of the invested industries and invested areas on operating efficiency and investment performance, this study uses the industry codes of CCIS, and separates the FDI enterprise in mainland China into the group of the information electronic \& communication equipment industry $(D I N D=1)$, and the group of other industries $(D I N D=0)$ for the mean-difference test. Samples of FDI enterprise from the information electronic \& communication equipment industry account for $43 \%$. As shown in Panel A of Table 2, if the FDI enterprise belongs to the information electronic \& communication equipment, its total technical efficiency (TE) is higher, and the $R O I$ is also higher than that of the other industries at a statistically significant level. Moreover, the subsidiary established years (YEARS), subsidiary capital density (CINT) and the parent company size (TSIZE) are significantly lower than other industries, but the subsidiary size (CSIZE), subsidiary debt-to-asset ratio (CDA), subsidiary turnover on PPE ( $P P T O)$, parent company R \& D ratio $(R D)$, parent company PPE ratio (PPE), parent company growth ratio (GROWTH), and parent company return on assets (TROA) are significantly higher than those of other industries.

Table 2. Univariate statistical results.

\begin{tabular}{|c|c|c|c|c|}
\hline Groups & $\begin{array}{c}\text { Panel A: } \\
\operatorname{DIND}(0,1)\end{array}$ & $\begin{array}{c}\text { Panel B: } \\
\text { AREA (0.1) }\end{array}$ & $\begin{array}{c}\text { Panel C: } \\
\text { ELEC }(0,1)\end{array}$ & $\begin{array}{c}\text { Panel D: } \\
\text { DTYPE }(0,1)\end{array}$ \\
\hline Variables & $\mathrm{t}-$ Value $^{\mathrm{a}}$ & t-Value ${ }^{\mathrm{a}}$ & $\mathrm{t}-$ Value $^{\mathrm{a}}$ & $\mathrm{t}-$ Value $^{\mathrm{a}}$ \\
\hline$T E(0,1)$ & $3.00^{* * *}$ & $-3.46^{* * *}$ & $1.75^{*}$ & -0.94 \\
\hline $\operatorname{PTE}(0,1)$ & 1.32 & $-3.25^{* * *}$ & 0.14 & $-1.77^{*}$ \\
\hline ROI (\%) & $2.39^{* *}$ & 1.15 & $3.04^{* * *}$ & $1.68^{*}$ \\
\hline YEARS & $-7.19^{* * *}$ & $-3.70^{* * *}$ & $-8.31^{* * *}$ & 1.23 \\
\hline CINT & $-7.35^{* * *}$ & $2.78^{* * *}$ & $-10.67^{* * *}$ & 0.30 \\
\hline$R D(\%)$ & $11.35^{* * *}$ & -0.03 & $16.09^{* * *}$ & $1.96^{*}$ \\
\hline AMOUNT $(\log )$ & -1.35 & $4.00^{* * *}$ & $-1.87^{*}$ & 0.35 \\
\hline CSIZE (log) & $4.49^{* * *}$ & $3.00^{* * *}$ & $4.45^{* * *}$ & 0.87 \\
\hline$C D A(\%)$ & $5.91^{* * *}$ & -0.67 & $7.04^{* * *}$ & 0.47 \\
\hline CROA (\%) & 0.60 & -0.92 & 0.37 & 0.73 \\
\hline РPTO (times) & $5.50^{* * *}$ & $-3.06^{* * *}$ & $6.22^{* * *}$ & 0.34 \\
\hline$R E(\%)$ & -0.38 & 1.65 & -0.89 & -0.15 \\
\hline PPE (\%) & $2.06^{* *}$ & $1.72^{*}$ & $1.92^{*}$ & -0.12 \\
\hline GROWTH (\%) & $4.59^{* * *}$ & $-1.93^{*}$ & $7.93^{* * *}$ & $1.86^{*}$ \\
\hline TROA (\%) & $2.41^{* *}$ & $-1.67^{*}$ & $4.48^{* * *}$ & $2.10^{* *}$ \\
\hline TDA (\%) & 0.25 & -1.28 & 0.31 & -0.71 \\
\hline TSIZE (log) & $-2.85^{* * *}$ & -0.75 & -3.54 & -0.50 \\
\hline
\end{tabular}

Notes: ${ }^{\mathrm{a}},{ }^{* * *},{ }^{* *},{ }^{*}$ denote significance at the $1 \%, 5 \%$, and $10 \%$ level, respectively and is two-tailed test. 
Different invested areas lead to different investment cost, transaction cost, transportation cost, tax cost, infrastructure, political risk, and employee quality. This paper sets the Taiwanese FDI enterprises in East China as the dummy variable $D A R E A=1$, and otherwise, $D A R E A=0$, to test whether there is any difference in operating efficiency and investment performance. As shown in Panel B, the total technical Efficiency (TE) and pure technical Efficiency (PTE) of FDI enterprises in East China are poorer than others and the subsidiary capital density (CINT), subsidiary size (CSIZE) and parent investment amount (AMOUNT) variables are significantly higher than others. However, the subsidiary established years (YEARS), subsidiary turnover on PPE (PPTO), parent company growth ratio (GROWTH) and parent company return on assets (TROA) are significantly lower than other invested areas. The result implies that many foreign companies entered the East region rapidly and demanded more labors and lands, thus results in increasing more operating costs than other areas. Moreover, the Chinese government provided more incentives to promoting the inland development. The East area has not competitiveness yet.

As shown in Panel $\mathrm{C}$, the parent companies belongs to the electronics industry $(E L E C=1)$, its total technical Efficiency (TE) is higher and its parent company's investment performance (ROI) is also higher at a statistically significant level. However, the subsidiary established years (YEARS), subsidiary capital density (CINT), parent investment amount (AMOUNT) and the parent company size (TSIZE) are significantly lower. The subsidiary size (CSIZE), subsidiary debt-to-asset ratio (CDA), subsidiary turnover on PPE (PPTO), parent company R \& D ratio $(R D)$, parent company PPE ratio $(P P E)$, parent company growth ratio (GROWTH) and parent company return on assets (TROA) are significantly higher than those of other industries.

Finally, this paper divides the samples by investment type into the wholly owned and joint ventures. As shown in Panel D, the pure technical Efficiency of the wholly owned subsidiary is poor, indicating that joint ventures have more accesses to cheaper human resources, natural resources (land, buildings), franchised rights and business licenses, as the local partners of the joint ventures are more familiar with the governmental rules and regulations. Hence, the joint ventures have fewer entry barriers into the Chinese market and better operating performance of the subsidiary. However, for the Taiwanese parent company, the joint ventures are more susceptible to local governmental interference, conflicts of objectives, and even take-over by the local partners. Therefore, the Taiwanese parent company's investment performance (ROI) is poorer. In addition, the wholly owned subsidiaries are significantly higher than the joint ventures in terms of RD, GROWTH and the TROA.

\subsection{Simultaneous Regression Analyses}

Table 3 shows the result of the association between the total operating efficiency (TE) of Taiwanese FDI enterprises in mainland China and the investment performance of their parent companies. The coefficient of the YEARS is positive, representing the operating efficiency of Taiwanese FDI enterprises with more established years is higher. The more established years in the Chinese market represent more investment experience, more market control power and human resources, and thus the operating efficiency will be higher. But it has not a statistically significant level. Thus, H1-1 is not supported. The coefficient of CINT is positive with statistically significant level, showing that the capital technology per employee is high and the total technical efficiency is better. The findings are consistent with Li et al. (2000), Chen \& Ku (2000). Hence, H1-2 is supported.

The regression coefficient of DAREA is -0.0194 is statistically significant, representing Taiwanese FDI enterprises located in East China have poorer technical efficiency. East region, which has the longest coastline in mainland China, has convenient transportation and advanced communications for Taiwanese and other foreign companies. With more foreign companies in East China, the infrastructure is more advanced and the quality of workers is better. However, the labor, natural resource and material cost increase accordingly and East-China is gradually losing investment location advantages. Many foreign companies gradually shift to other regions. Therefore, H1-3 is supported. Taiwanese FDI enterprises in East China have lower operating efficiency.

According to the empirical results of the parent company's investment performance (ROI), the regression coefficient of TE is positive with statistically significant, as expected in H2-1. The investment performance of Taiwanese FDI enterprises with higher operating efficiency in mainland China is better. This study expects Taiwanese parent companies with more R \& D expenses have better investment performance. Due to the uncertainty, the coefficient of $R D$ is negative, H2-2 is not supported. This finding is consistent with Hitt et al. (1997), and Bharadwaj et al. (1999).

Shown in Table 3, Taiwanese parent companies with higher investment amounts (AMOUNT) in mainland 
Table 3. Results of simultaneously regression analyses.

\begin{tabular}{|c|c|c|c|c|c|}
\hline \multicolumn{2}{|c|}{ Models } & \multicolumn{2}{|c|}{ Y: TE Equation (2) } & \multicolumn{2}{|c|}{ Y: ROI Equation (3) } \\
\hline Variables & Pred. Sign. & $\begin{array}{l}\text { Parameter } \\
\text { Estimate }\end{array}$ & $p$-Value & $\begin{array}{l}\text { Parameter } \\
\text { Estimate }\end{array}$ & $p$-Value \\
\hline Intercept & & 0.0091 & 0.9049 & 43.254 & 0.0823 \\
\hline YEARS & + & 0.0020 & 0.1290 & & \\
\hline CINT & + & $0.0001^{* * *}$ & $<0.0001$ & & \\
\hline DAREA & - & $-0.0194^{* *}$ & 0.0377 & & \\
\hline DIND & & 0.0016 & 0.8692 & & \\
\hline CSIZE & & 0.0014 & $(0.7671)$ & & \\
\hline$C D A$ & & $0.0007^{* *}$ & 0.0132 & & \\
\hline CROA & & $0.0013^{* * *}$ & 0.0015 & & \\
\hline РРТО & & $0.0087^{* * *}$ & $<0.0001$ & & \\
\hline CGDP & & 0.0011 & 0.7262 & & \\
\hline$T E$ & + & & & $32.7755^{* * *}$ & 0.0045 \\
\hline$R D$ & + & & & $-2.9329^{* *}$ & 0.0256 \\
\hline AMOUNT & + & & & $5.3321^{* * *}$ & 0.0029 \\
\hline DTYPE & + & & & $8.0782^{*}$ & 0.0645 \\
\hline$E L E C$ & & & & $10.9830^{* * *}$ & 0.0028 \\
\hline$R E$ & & & & 0.0738 & 0.2208 \\
\hline$P P E$ & & & & 0.4997 & 0.3464 \\
\hline GROWTH & & & & -0.0233 & 0.3673 \\
\hline TROA & & & & $0.6760^{* *}$ & 0.0445 \\
\hline$T D A$ & & & & $-0.2291^{*}$ & 0.0630 \\
\hline TSIZE & & & & $-6.6085^{* * *}$ & $<0.0001$ \\
\hline$T G D P$ & & & & 0.4251 & 0.3441 \\
\hline & & & ted R-Square & & \\
\hline
\end{tabular}

China have better investment performance, and thus H2-3 is supported. The wholly owned FDI enterprises with better understanding of the business goals of the parent company have a positive impact with statistically significance on the investment performance of the parent company. Therefore, H2-4 is supported.

\section{Conclusion}

This study applied DEA and SURE methods to explore the association between the operating efficiency of Taiwanese FDI enterprises in mainland China and the investment performance of their parent companies. We find that Taiwanese FDI enterprises with longer established years in the Chinese market have greater operating efficiency. Due to familiarity and adaption with local politics, culture and law, they have better political, social and economic relationship and capabilities to prevent subsequent competitors, and thus the operating efficiency is better. We also find that the operating efficiency of Taiwanese FDI enterprises with higher capital intensity is higher. The more capital investment focusing on more technology equipment can effectively increase output, reduce product unit cost, improve product quality, and produce diversified products, thus the operating efficiency of FDI firm is better. Furthermore, due to many foreign companies entered the East region rapidly, demanded 
more labors and lands, and the Chinese government provided more incentives to promoting the inland growth, thus Taiwanese FDI enterprises located in East China do not have greater operating efficiency than other areas.

In addition, we find that the Taiwanese parent companies with higher operating efficiency of FDI enterprises in mainland China have better investment performance. The Taiwanese parent companies with higher R \& D expenditure percentages do not have improved investment performance because of a lack of spillover to FDI subsidiaries or more uncertain factors. The Taiwanese parent companies with greater investment of FDI enterprises in mainland China also have higher investment performance attributed to internationalization benefits. Finally, the wholly-owned investment type of a parent enterprise has greater investment performance than jointventure investment type. The wholly-owned FDI investment is not susceptible to risks of conflicting goals, business principles and being taken over by the local partners, and the parent companies have more power for operating decisions and market control, thus they have better investment performance.

This study has implications for government policy making and management performance improvement. First, this study can provide evidence for government policy and parent companies' investment activities. Given an increasingly competitive environment where inefficient enterprises are difficult to survive, it is imperative for them to be knowledgeable about operating efficiency of FDI in mainland China, as well as the impacts on the parent company and factors that may improve or exacerbate performance. Second, this study found that the wholly owned investment model results in better investment performance than joint venture model, because the former has better control over the business operation and decision-making. The capital intensive FDI enterprises in mainland China have better operating efficiency than labor intensive enterprises. These findings suggest that FDI can enhance the competitiveness of the parent companies.

However, a limitation of this study was that the research period was from 2004 to 2007 because the detailed financial data of subsidiaries in mainland China could not be obtained after 2008. Since the enactment of the new Corporate Income Tax Law and the Labor Contract Law on January 1, 2008, the corporate income tax has been unified at $25 \%$, which was increased from the preferential $15 \%$ to $25 \%$. Meanwhile, the preferential treatment of foreign manufacturers, including tax exemption, rebates, and preferential tax rate for specific regions has been terminated. The new tax system can result in the validity of the empirical data of this study.

\section{References}

Banker, R. D., \& Natarajan, R. (2008). Evaluating Contextual Variables Affecting Productivity. Operations Research, 56, 48-58. http://dx.doi.org/10.1287/opre.1070.0460

Banker, R. D., Charnes, A., \& Cooper, W. W. (1984). Some Models for Estimating Technical and Scale Inefficiencies in Data Envelopment Analysis. Management Science, 30, 1078-1092. http://dx.doi.org/10.1287/mnsc.30.9.1078

Barney, J. B. (1986). Strategic Factor Markets: Expectations, Luck, and Business Strategy. Management Science, 32, 12311241. http://dx.doi.org/10.1287/mnsc.32.10.1231

Beamish, P. W., \& Jiang, R. (2002). Investing Profitably in China: Is it Getting Harder? Long Range Planning, 35, $135-151$. http://dx.doi.org/10.1016/S0024-6301(02)00033-X

Bharadwaj, A. S., Bharadwaj, S. G., \& Konsynski, B. R. (1999). Information Technology Effects on Firm Performance as Measured by Tobin's Q. Management Science, 45, 1008-1024. http://dx.doi.org/10.1287/mnsc.45.7.1008

Charnes, A., Cooper, W. W., \& Rhodes, E. (1978). Measuring the Efficiency of Decision Making Units. European Journal of Operations Research, 2, 429-444. http://dx.doi.org/10.1016/0377-2217(78)90138-8

Chen, C., \& Yeh, C. (2012). Re-Examining Location Antecedents and Pace of Foreign Direct Investment: Evidence from Taiwanese Investments in China. Journal of Business Research, 65, 1171-1178.

http://dx.doi.org/10.1016/j.jbusres.2011.07.032

Chen, T., \& Ku, Y. (2000). The Effect of Foreign Direct Investment on Firm Growth: The Case of Taiwan’s Manufacturers. Japan and the World Economy, 12, 153-172. http://dx.doi.org/10.1016/S0922-1425(99)00035-3

Düzakin, E., \& Düzakin, H. (2007). Measuring the Performance of Manufacturing Firms with Super Slacks Based Model of Data Envelopment Analysis: An Application of 500 Major Industrial Enterprises in Turkey. European Journal of Operational Research, 182, 1412-1432. http://dx.doi.org/10.1016/j.ejor.2006.09.036

Foster, M. (2011). Distribution of FDI across China-Common Policies but Differing Impacts by Region. Journal of Chinese Economic and Foreign Trade Studies, 4, 125-138. http://dx.doi.org/10.1108/175444401111143463

Fung, L., Liu, J., \& Wang, F. (2013). Are FDI in China and Parent Firm Exports Substitutes or Complements? An Empirical Study of Taiwanese Manufacturing Firms. Taiwan Economic Review, 41, 167-194. 
Goto, A., \& Suzuki, K. (1989). R \& D Capital, Rate of Return on R \& D Investment and Spillover of R \& D in Japanese Manufacturing Industries. Review of Economics and Statistics, 71, 555-564. http://dx.doi.org/10.2307/1928096

Green, J., Stark, P. W., \& Thomas, M. (1996). UK Evidence on the Market Valuation of Research and Development Expenditures. Journal of Business Finance and Accounting, 23, 191-216. http://dx.doi.org/10.1111/j.1468-5957.1996.tb00906.x

Guo, D., \& Jiang, K. (2013). Venture Capital Investment and the Performance of Entrepreneurial Firms: Evidence from China. Journal of Corporate Finance, 22, 375-395. http://dx.doi.org/10.1016/j.jcorpfin.2013.07.001

Hennart, J. F. (1991). The Transaction Costs Theory of Joint Ventures: An Empirical Study of Japanese Subsidiaries in the United States. Management Science, 37, 483-497. http://dx.doi.org/10.1287/mnsc.37.4.483

Hitt, M. A., Hoskisson, R. E., \& Kim, H. (1997). International Diversification: Effects on Innovation and Firm Performance in Product-Diversified Firms. Academy of Management Journal, 40, 767-798. http://dx.doi.org/10.2307/256948

Hu, M., \& Chen, H. (1996). An Empirical Analysis of Factors Explaining Foreign Joint Venture Performance in China. Journal of Business Research, 35, 165-173. http://dx.doi.org/10.1016/0148-2963(95)00087-9

Klette, T. J. (1996). R \& D, Scope Economies, and Plant Performance. Rand Journal of Economics, 27, 502-522.

Klimberg, R. K., \& Ratick, S. J. (2008). Modeling Data Envelopment Analysis (DEA) Efficient Location/Allocation Decision. Computers \& Operations Research, 35, 457-474. http://dx.doi.org/10.1016/j.cor.2006.03.010

Lev, B., \& Sougiannis, T. (1996). The Capitalization, Amortization and Value Relevance of R \& D. Journal of Accounting and Economics, 21, 107-138. http://dx.doi.org/10.1016/0165-4101(95)00410-6

Li, J., Qian, G., Lam, K., \& Wang, D. (2000). Breaking into China: Strategic Considerations for Multinational Corporations. Long Range Planning, 33, 673-687. http://dx.doi.org/10.1016/S0024-6301(00)00077-7

Lin, F. (2010). The Determinants of Foreign Direct Investment in China: The Case of Taiwanese Firms in the IT Industry. Journal of Business Research, 63, 479-485. http://dx.doi.org/10.1016/j.jbusres.2009.04.005

Liu, K., \& Daly, K. (2011). Foreign Direct Investment in China Manufacturing Industry-Transformation from a Low Tech to High Tech Manufacturing. International Journal of Business and Management, 6, 15-27. http://dx.doi.org/10.5539/ijbm.v6n7p15

Liu, K., Daly, K., \& Varua, M. (2012). Determinants of Regional Distribution of FDI Inflows across China’s Four Regions. International Business Research, 5, 119-126. http://dx.doi.org/10.5539/ibr.v5n12p119

Lu, W., \& Hung, S. (2010). Performance Efficiency of offshore Business Groups in China-How Taiwanese Firms Perform. Asia Pacific Management Review, 15, 391-412.

Ma, Y. F., \& Goo, Y. J. (2005). Technical Efficiency and Productivity Change in China's High- and New-Technology Industry Development Zones. Asian Business and Management, 4, 331-355.

http://dx.doi.org/10.1057/palgrave.abm.9200135

Oberholzer, M. (2013). A Non-Parametric Comparison among Firms’ Income Statement-Based and Balance Sheet-Based Performance. International Business \& Economics Research Journal, 12, 1467-1478.

Pan, Y., Li, S., \& Tse, D. K. (1999). The Impact of Order and Mode of Market Entry on Profitability and Market Share. Journal of International Business Studies, 30, 81-103. http://dx.doi.org/10.1057/palgrave.jibs.8490061

Sharma, M., Wang, M., \& Wong, M. (2014). FDI Location and the Relevance of Spatial Linkages: Evidence from Provincial and Industry FDI in China. Review of International Economics, 22, 86-104. http://dx.doi.org/10.1111/roie.12098

Shiu, A. (2002). Efficiency of Chinese Enterprise. Journal of Productivity Analysis, 18, 255-267. http://dx.doi.org/10.1023/A:1020690811711

Sougiannis, T. (1994). The Accounting Based Valuation of Corporate R \& D. The Accounting Review, 69, 44-68.

Tsai, H. C., Chen, C. M., \& Tzeng, G. H. (2006). The Comparative Productivity Efficiency for Global Telecoms. International Journal of Production Economics, 103, 509-526. http://dx.doi.org/10.1016/j.ijpe.2005.11.001

Wei, Z., Varela, O., \& Hassan, M. K. (2002). Ownership and Performance in Chinese Manufacturing Industry. Journal of Multinational Financial Management, 12, 61-78. http://dx.doi.org/10.1016/S1042-444X(01)00026-3

Yu, S., \& Shen, C. (2013). Geographic Proximity and Location Choice of Foreign Direct Investment in China. Asian Business \& Management, 12, 351-380. http://dx.doi.org/10.1057/abm.2013.4

Zhong, W., Yuan, W., Lin, S., \& Huang, Z. (2011). The Performance Evaluation of Regional R \& D Investments in China: An Application of DEA Based on the First Official China Economic Census Data. Omega, 39, 447-455.

http://dx.doi.org/10.1016/j.omega.2010.09.004 
Scientific Research Publishing (SCIRP) is one of the largest Open Access journal publishers. It is currently publishing more than 200 open access, online, peer-reviewed journals covering a wide range of academic disciplines. SCIRP serves the worldwide academic communities and contributes to the progress and application of science with its publication.

Other selected journals from SCIRP are listed as below. Submit your manuscript to us via either submit@scirp.org or Online Submission Portal.
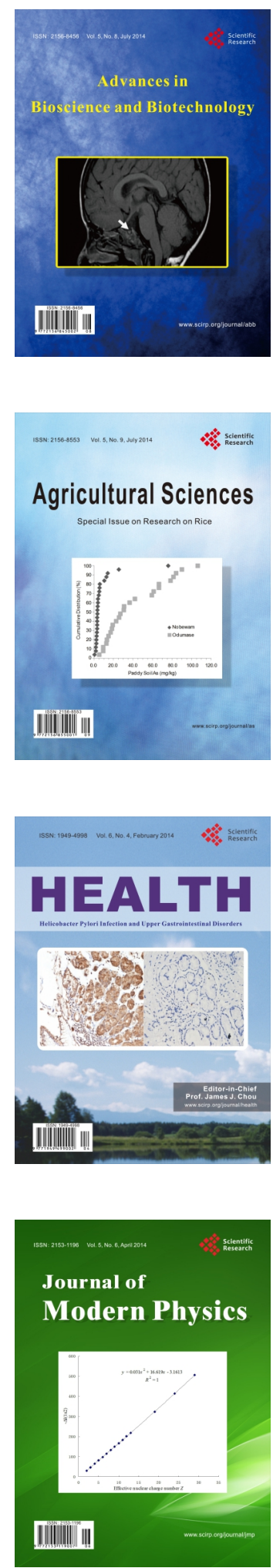
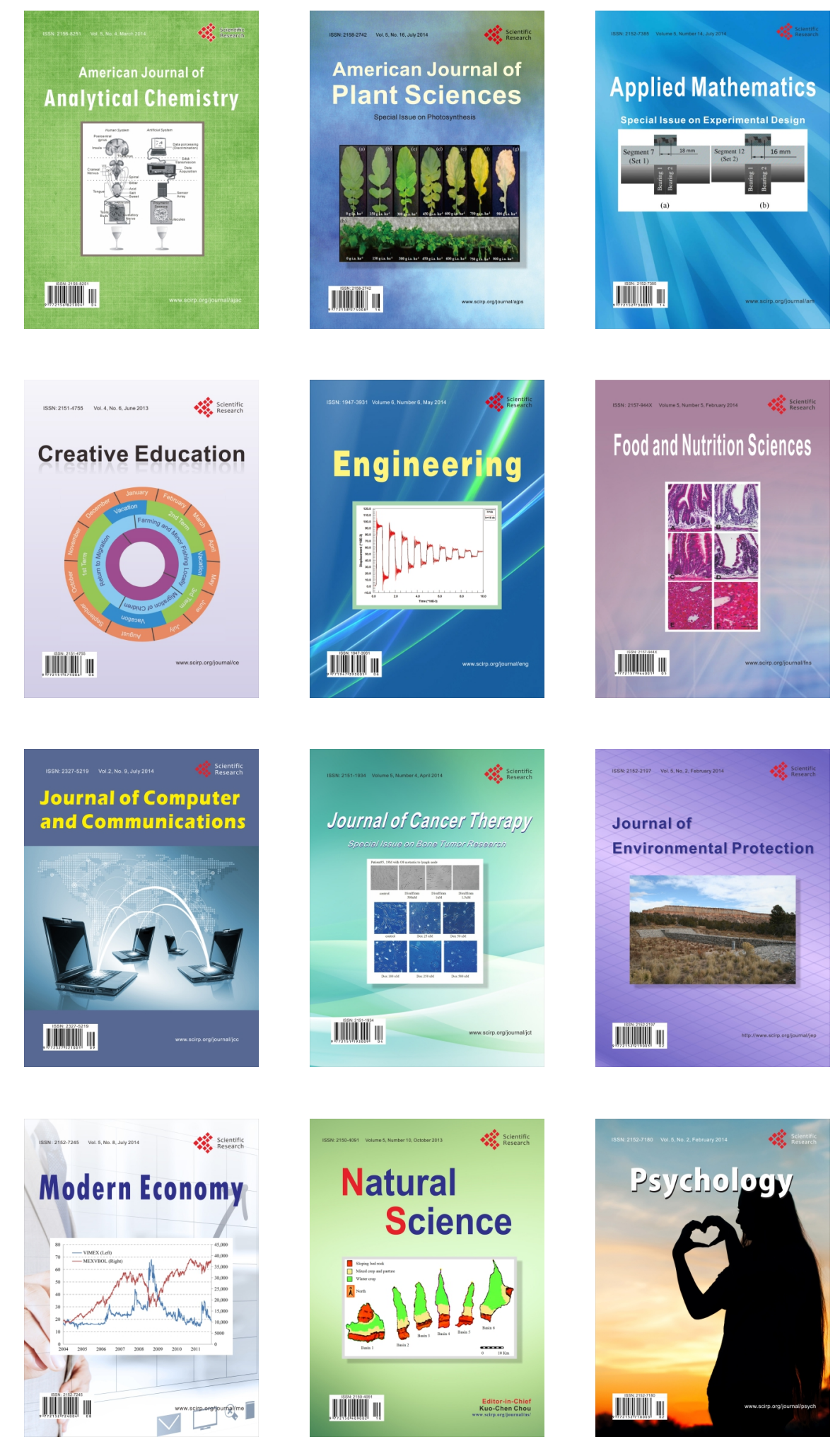